\title{
Wastewater and Magnetized Wastewater Effects on Soil Erosion in Furrow Irrigation
}

\author{
Hamid Raeisi-Vanani ${ }^{1}$, Ali Reza Soltani-Toudeshki ${ }^{2}$, Mohammad Shayannejad ${ }^{3}$, \\ Kaveh Ostad-Ali-Askari ${ }^{4 *}$, Amin Ramesh ${ }^{5}$, Vijay P. Singh ${ }^{6}$,Saeid Eslamian ${ }^{7}$ \\ 1, 2,3, 5,7 Water Engineering Department, Isfahan University of Technology, Isfahan, Iran. \\ ${ }^{4}$ *Department of Civil Engineering,Isfahan (Khorasgan) Branch,Islamic Azad University,Isfahan Iran \\ ${ }^{6}$ Department of Biological and Agricultural Engineering \& Zachry Department of Civil Engineering, \\ Texas A and M University, Texas, U.S.A. \\ *Corresponding author: Kaveh Ostad-Ali-Askari, Faculty Member, Department of Civil Engineering, Isfahan \\ (Khorasgan) Branch, Islamic Azad University, Isfahan, Iran. Email: koa.askari@khuisf.ac.ir

\begin{abstract}
In this paper we investigated the effects of fresh water ( $F$ as a control), wastewater $(W)$ and magnetized wastewater $(M)$ on furrow erosion. Experimental design was randomized complete blocks consisting of four replication blocks and three water quality treatments. Five irrigation events with 4 days' irrigation irrigation events for each furrow. Water quality parameters measured during the irrigation ventsd included cations, anions, EC, pH, total-coliform, TSS, DO and COD. The applied intensity of the magnetic field was 10 mili-Tesla. Furrows spacing, length and slope were $0.6 \mathrm{~m}, 42 \mathrm{~m}$ and $0.11 \%$, respectively. Inflow rate was $0.8 \mathrm{l} / \mathrm{s}$ for all the irrigation evens. To determine the net erosion in furrows, water samples were taken from runoff after its start at different time intervals. The net erosion was calculated at each time after determining soil mass in the samples and the net erosion vs. time chart was plotted. The mean erosion was calculated from this chart. The erosion indexes investigated in this study include mean erosion and maximum depth of the furrow crosssection. The results showed that, in all of the water treatments, the net erosion decreases with time in each irrigation., There is also a significant decrease in the mean erosion values in $W$ and $M$ treatments, compared with $F$ treatment, in the second and fourth irrigation events at the $1 \%(p<0.01)$ and $5 \%(p<0.05)$ level, respectively, but there no significant difference between $W$ and $M$ treatments. The effect of irrigation event on the mean erosion was not significant in any treatment. The effect of water treatment on the basic infiltration rate and the maximum depth of furrow cross-section were not significant, but the basic infiltration rate was in most cases higher in $M$ treatment than in $F$ and $W$ treatments in most cases. Also the changes in the maximum depth of furrow cross-section due to subsequent irrigation events were smaller in $M$ and $W$ treatments than in $F$ treatment.
\end{abstract} \\ interval were practiced in each furrow. The erosion was monitored and measured in the second, fourth and fifth
}

Keywords: Water quality; Wastewater; Magnetic field; Magnetized wastewater; Runoff; Furrow erosion; Net erosion

\section{INTRODUCTION}

\subsection{Soil Erosion}

Erosion due to irrigation has been studied primarily in North America in 1940 (KOLUVEK et al, 1993). Irrigation-induced erosion and subsequent sediment loss is a serious agricultural and environmental problem (CARTER et al, 1993). Soil erosion decreases soil productivity, because, for example, the furrow erosion on irrigated land decreases topsoil depth in the upslope part of the field area and may increase the topsoil depth in the downslope part, reducing thereby the soil productivity potential (CARTER, 1993). Erosion is more common when water moves in small channels called furrows (TROUT and NEIBLING, 1993). Soil erosion due to irrigation, especially furrow irrigation, contributes to the nonpoint-source pollution of water (HAJEK et al., 1990) and is a serious threat to crop productivity in many regions (CARTER, 1993). It may damage water quality in rivers, lakes and streams (BJORNEBERG et al., 2005). A large amount of farm soil may be lost due to furrow erosion 
caused by runoff from furrows that transfers sediment (CARTER, 1993). Soil erosion and thus increase of the suspended solids amounts, causes water turbidity increasing and also decreasing of the water storage capacity of small reservoirs for the upstream residents. Turbidity fluctuating by erosion makes water treatment difficult and also results in the decrease of water storage capacity in the dams. When turbidity concentration increases thus using of chlorine increases for water treatment. To avoid these problems should be done integrated land use management to good maintain of surface water quality (STHIANNOPKAO et al, 2007). Erosion reduces soil physical quality indexes such as water holding capacity and soil structural stability (WALLACE and TERRY, 1998).

Three main factors influencing furrow erosion are the shear stress of flowing water on the furrow perimeter, cohesivity of soil particles (which affects the stability and size distribution characteristics of furrow soil), and stream transport capacity (KEMPER et al., 1985; TROUT and NEIBLING, 1993). Hydraulic forces of water movement and soil parameters such as aggregate stability and particle size will determine erosion and sedimentation (CLEMMENS and BJORNEBERG, 2005). FORNSTORM et al (1985) reported that furrow erosion has more dependence to flow rate, slope, soil texture, furrow length and cross-section (FORNSTORM et al., 1985). BROWN et al (1989) found that in more of the furrows, the furrow cross-section creates by erosion at the first test and will not change significantly during the next experiments (BROWN et al., 1989).

\subsection{Water Quality Effect on Soil Erosion}

Water quality is one of the important factors in furrow erosion that there are few studies about it. Water quality may influence flow shear by controlling furrow intake and, hence, down furrow flow rate (FIREMAN and BODMAN, 1940; QUIRK and SCHOFIELD, 1955; FRENKEL et al., 1978). Water quality affected soil cohesivity by altering clay dispersion (VELASCO-MOLINA et al., 1971; FRENKEL et al., 1978; MALIK et al., 1992; SHAINBERG et al., 1992) and aggregate stability characteristics in furrow irrigation (SMITH et al., 1992).

Water chemistry may influence the sediment transport capacity of the furrow stream indirectly via impacts on flow shear (i. e. infiltration-induced flow rate effects), and by modifying the character of entrained soil particles and aggregates. Water quality affected flocculation, which determined the size and density of detached soil materials (ARORA and COLEMAN, 1979; GOLDBERG and GLAUBIG, 1987).

WISCHMEIER and MANNERING (1969) reported that water acidity increases the amount of erosion (WISCHMEIER and MANNERING, 1969).

Increasing EC of irrigation water enhanced soil flocculation (ARORA and COLEMAN, 1979) and increased settling rates of sediment suspended in water (ROBBINS and BRICKWAY, 1978). LENTZ et al. (1996) determined that main effects for water quality, traffic, and first vs. second irrigations were significant for total soil loss, mean sediment concentration, total outflow, net infiltration and advance time. Average tail-water soil losses was also most for low EC/high SAR of water treatments and net infiltration decreased $14 \%$ in high SAR compared with low SAR treatments too. Soil loss increased $68 \%$ for second irrigations, and net infiltration fell $23 \%$ in trafficked furrows, but waterquality effects were the same (LENTZ et al, 1996).

\subsection{Wastewater and its Effect on Soil Properties}

Wastewater irrigatin can be useful for decreasing of erosion and desertification, because arable lands continue to be degraded by erosion and desertification and compost made with municipal waste could be used to increase the nutrition and water-holding capacity of the soils at risk of desertification, thereby maintaining productivity and soil stability near the edge of the desert (MADISON et al, 2004). Irrigation is an excellent user for sewage effluent consumption because sewage effluent is mostly water with nutrients. Using wastewater for irrigation is unrestricted provided it has no adverse effects on crops, soils, animals and humans (BOUWER and IDELOVITCH, 1987).

Effects of irrigation with treated wastewater on soil properties were investigated in many researchers. For example, a four-year study observed a significant decrease of $\mathrm{pH}$ and infiltration rate, and a significant increase of organic matter (OM), sodium adsorption ratio (SAR) and electrical conductivity (EC) in the soil irrigated with treated wastewater rather than well water or rain-falls. 
Significant reduction of the water infiltration rate caused by a seal formation was mainly attributed to the accumulation of suspended solids, and partially to clay dispersion and microbiological activity (BEDBABIS et al, 2014). Wastewater irrigation significantly affected soil $\mathrm{K}$ but not soil $\mathrm{P}$ and total soil N. Change of irrigation system can be causes different effects when using treated wastewater too: studies show that surface irrigation than subsurface irrigation significantly decreases soil EC, Sodium (Na) and Magnesium (Mg) at depth of 0-15 cm (HEIDARPOUR et al, 2007). About wastewater effect on soil clogging was found that this phenomenon development is highly correlated with the cumulative mass density loadings of total biochemical oxygen demand and suspended solids (SIEGRIST and BOYLE, 1987). This phenomenon results infiltration decreasing.

SEPASKHAH and SHAHABIZAD (2010) found wastewater causes greater irrigation runoff and soil erosion than freshwater. This occurred due to the differences in quality of wastewater and freshwater (SEPASKHAH and SHAHABIZAD, 2010). It is anticipated that application of the wastewater with higher values of EC and SAR dispersed the soil particles and resulted in crust formation on the soil surface (KAZMAN et al, 1983 and MAMEDOV et al, 2000). Runoff and soil loss from the treated wastewater (with less EC) were significantly lower than those from the saline-sodic water (MANDAL et al, 2008).

\subsection{Magnetized Water}

Application of magnetized water for irrigation is recommended to save irrigation water. Because for example the researches show that the mean soil moisture contents at below the emitter for the magnetized irrigation water are more than the nonmagnetized irrigation water, and the differences are significant, as the irrigation with magnetic water as compared with the non-magnetic water increases highly significant soil moisture up to 7.5\% (MOSTAFAZADEH-FARD et al, 2011). According to these results, the use of magnetized water in trickle irrigation reclaim soils with high cations and anions content such as calcium, sodium, and bicarbonate. Studies showed that magnetized irrigation water decreases mean soil cations (such as calcium, sodium, and magnesium) and anions (such as bicarbonate, chloride, and sulfate) in soil below the emitter relative to nonmagnetized irrigation water. This was caused by greater leaching of soil salt by the magnetized irrigation water (MOSTAFAZADEH-FARD et al, 2012). Moreover, the magnetized water increased yield and yield component traits of all crops (HOZAYN et al, 2011).

( OSTAD-ALI-ASKARI et al, 2015 and OSTAD-ALI-ASKARI et al, 2016 and OSTAD-ALIASKARI et al, 2017).

Because of the erosion importance and the extensive use of treated wastewater in irrigation, in this paper wastewater effects on soil erosion were investigated in furrow irrigation. Application of magnetic field technology was also investigated in this subject as magnetized wastewater.

(OSTAD-ALI-ASKARI et al, 2015 and OSTAD-ALI-ASKARI et al, 2016 and OSTAD-ALIASKARI et al, 2017 and SAYEDIPOUR et al, 2015).

\section{MATERIALS AND MethodS}

\subsection{Experimental}

For investigation of wastewater and magnetized wastewater effects on soil erosion in furrow irrigation a farm research was selected in Isfahan University of Technology (Location: N 32 $42^{\prime}$ and E051 $32^{\prime}$ ') in year 2013 for 6 months. The climate of this region was hot and dry and measured air temperature at the weather station in field was from $24.9{ }^{\circ} \mathrm{C}$ to $40^{\circ} \mathrm{C}$ during all of the experiments.

Some of field soil properties are shown in Table 1.

Table 1. Properties of soil (plow layer)

\begin{tabular}{|c|c|c|c|c|c|c|c|c|c|}
\hline \multirow[b]{2}{*}{$\begin{array}{l}\text { Depth } \\
\mathrm{cm}\end{array}$} & \multicolumn{3}{|c|}{ Particle-size distribution } & \multirow[b]{2}{*}{$\begin{array}{c}\text { Textural class } \\
\text { USDA }\end{array}$} & \multirow{2}{*}{$\begin{array}{c}\text { Organic } \\
\text { materials } \\
\%\end{array}$} & \multirow[b]{2}{*}{$\begin{array}{l}\mathrm{EC}_{\mathrm{e}} \\
\mathrm{ds} / \mathrm{m}\end{array}$} & \multirow[b]{2}{*}{$\begin{array}{c}\mathrm{pH}_{\mathrm{e}} \\
- \\
-\end{array}$} & \multirow{2}{*}{$\begin{array}{c}\text { Bulk } \\
\text { density } \\
\mathrm{gr} / \mathrm{cm}^{3}\end{array}$} & \multirow{2}{*}{$\begin{array}{c}\text { Initial } \\
\text { volumetric } \\
\text { moisture } \\
\%\end{array}$} \\
\hline & $\begin{array}{c}\text { Sand } \\
\%\end{array}$ & $\begin{array}{l}\text { Silt } \\
\%\end{array}$ & $\begin{array}{c}\text { Clay } \\
\%\end{array}$ & & & & & & \\
\hline-15 & 50.4 & 21.8 & 27.8 & $\mathrm{Sa}$ & $<1$ & 4 & 7.28 & 1.4 & 4.0 \\
\hline $5-40$ & 52.3 & 20.3 & 27.4 & Sandy clay loam & $<1$ & $0.81-2.49$ & $7.51-8.50$ & $1.56-1.79$ & 4.2 \\
\hline
\end{tabular}

Note: $E C e=$ Saturation extract electrical conductivity; $p H e=$ Saturation extract acidity.

As can be seen in Table 1, soil texture is coarse and initial soil moisture is low. 
Three water-quality treatments were used consisted of fresh water ( $\mathrm{F}$ as control treatment), effluent of wastewater (W) taken from an aeration lagoon (Fig1) and magnetized of the same effluent (M).
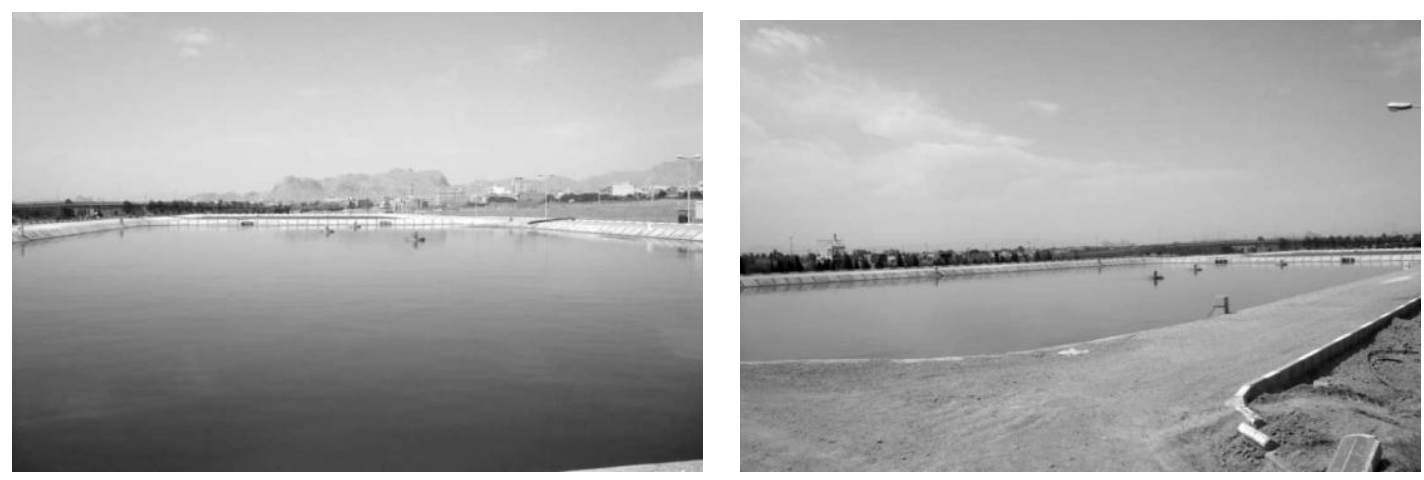

Fig1. Urban wastewater treatment plant with aeration lagoon method from two sides

To water transfer into the furrow head with constant inflow rate, a set was used consists of tanks of water supply, reservoir under constant head (Fig. 2) and flexible gated pipe. Two tanks were used to water supply with a total volume of 16 cubic meters in upstream end. A concrete stand with height of $60 \mathrm{~cm}$ was also built for creating of hydraulic gradient to water transfer from tanks to reservoir and then tanks were put on it. This stand was caused height difference of about $30 \mathrm{~cm}$ between tanks outlet and reservoir inlet. Two brass floater valves of 2 inches were also used to fix of water level in the reservoir.

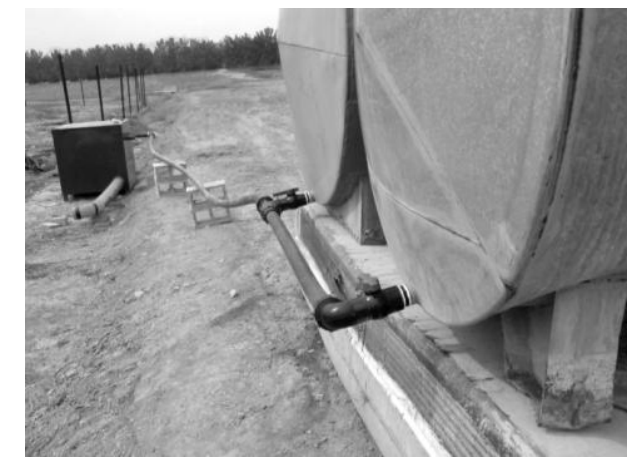

Fig 2. Wastewater and fresh water reservoirs and stabilizer reservoir of water level

Implementation operations of the research were started with tillage. At this stage, plowing operations, disking and roller-harrowing were done on the field. Then regular gridding was done by surveying and then field was leveled. In next step non-wheel traffic furrows with spacing $0.6 \mathrm{~m}$, slop $0.11 \%$ and $42 \mathrm{~m}$ length were made via furrower set. After tillage and furrow making, field slope was determined and then using conditions of maximum recommended non-erosive stream size (given by $Q=0.6 / \mathrm{s}$ where $Q$ is the furrow inflow rate, $1 / \mathrm{sec}$, and $s$ is the furrow slope in percent) and a constant flow rate taken from the water reservoir, the inflow rate was determined $0.8 \mathrm{l} / \mathrm{sec}$ in each furrow.
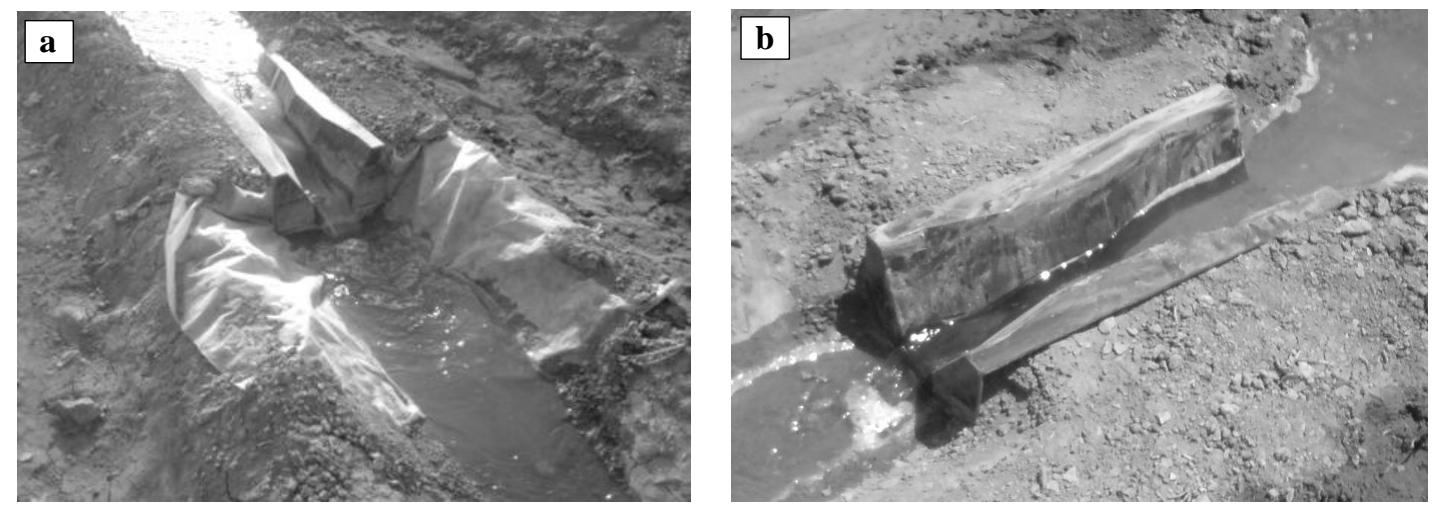

Fig3. Inflow rate measurement (3a); Outflow rate measurement; and sampling of runoff from here (3b)

Gated pipe was attached to the reservoir outlet and using a graduated container and a timer, opening amounts of the valves on the gated pipe were marked for exact creating of the requirement inflow rate 
$(0.8 \mathrm{l} / \mathrm{sec})$ and then were opened for specified amount in each experiment. Experiments of related to $\mathrm{F}$ treatment were done firstly then for $\mathrm{W}$ and $\mathrm{M}$ treatments (i. e. gated pipe was used just for $\mathrm{F}$ treatment in 20 first irrigation events then for $\mathrm{W}$ and $\mathrm{M}$ treatments in 40 next tests).

Inflow and outflow rate were measured with $\mathrm{WSC}^{1}$ flumes of type 2 (Fig3a, b) and their hydrographs were plotted. Basic infiltration rate $\left(f_{o}\right)$ was calculated from the difference between fixed inflow and outflow rate and dividing this difference by the length of the furrow

Five irrigations were applied to in each furrow every 4 days. Soils were with no planting. The erosion was monitored and measured in the second, fourth and fiveth irrigation events for each furrow.

The magnetic set was consisting of three magnets each with a $10 \mathrm{mT}$ intensity of the magnetic field. Magnets were closed around of the gated pipe with angle of 120 degrees (Fig4).

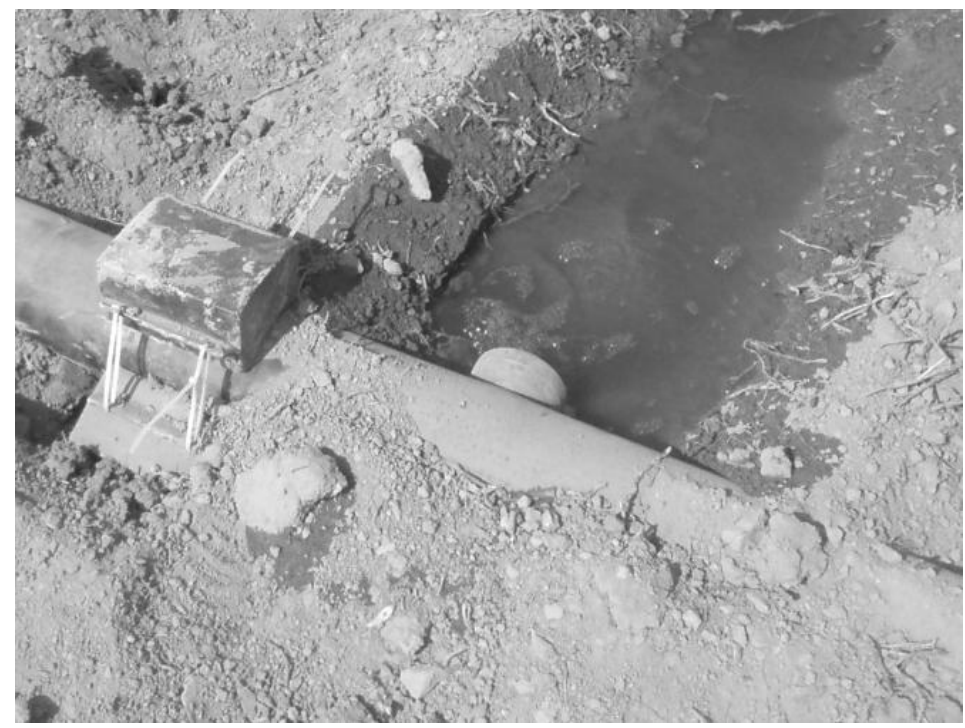

Fig4. Magnetic set; magnetized wastewater; and gated pipe

Inflow water-quality parameters were measured at three times before the second, fourth and fiveth irrigation events. These parameters were consists of cations $\left(\mathrm{Na}^{+}, \mathrm{K}^{+}, \mathrm{Ca}^{2+}\right.$ and $\left.\mathrm{Mg}^{2+}\right)$, anions $\left(\mathrm{HCO}_{3}{ }^{-}\right.$, $\mathrm{CO}_{3}{ }^{2-}, \mathrm{SO}_{4}{ }^{2-}$ and $\left.\mathrm{Cl}^{-}\right), \mathrm{EC}, \mathrm{pH}$, total-coliforms ${ }^{1}$, TSS, DO and COD. Total-coliform and COD were measured via multiple-tube fermentation and closed reflux spectrophotometric tests respectively. Fresh water quality was almost constant in all experiments. Water quality experiments were done based on standard methods for the examination of water and wastewater (ANONYMOUS, 1998).

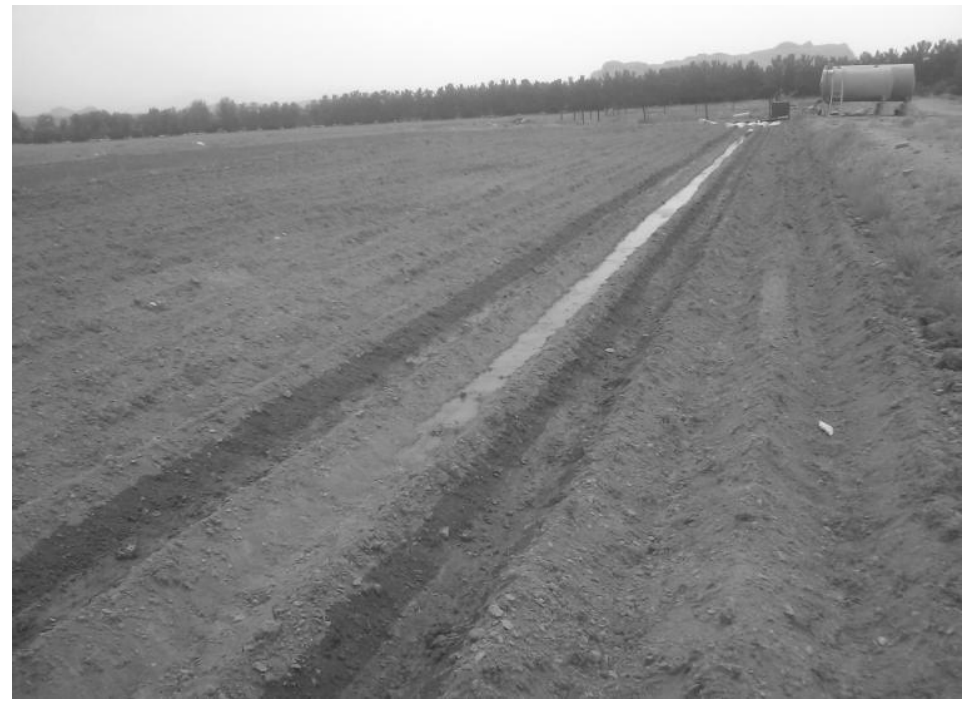

Fig 5. Main and lateral furrows; water advance to end

The net erosion (sediment lost in runoff) was detrmined for each furrow using of KOLUVEK et al (1993) method. After starting of runoff (after water advance to the furrow end (Fig. 5)), samples were taked from it (Fig. 3b) at different time intervals. 


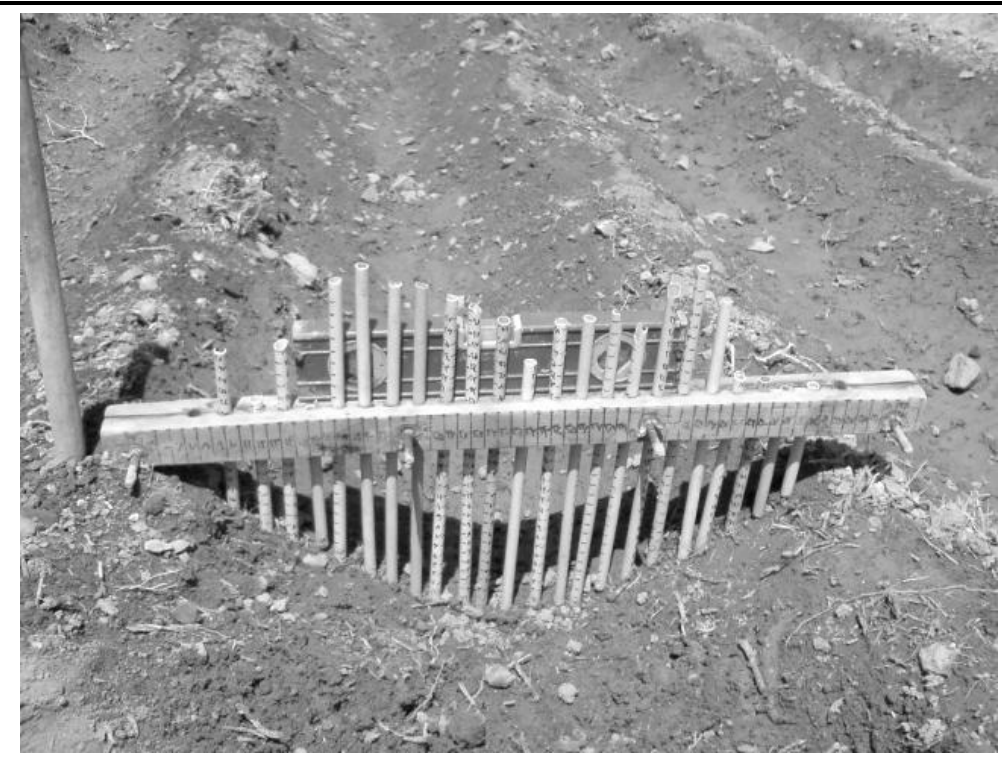

Fig6. Profile Meter Set

Samples volume was the same at each time. 4 or 5 samples were taken during each irrigation event form start to end time of the runoff at specific time intervals (nearly every 5 minutes). The runoff samples were dried in oven at $105^{\circ} \mathrm{C}$ for 24 hours to measure soil mass value. Then sediment mass determined by difference of wet and dry mass.

(OSTAD-ALI-ASKARI et al, 2015 and OSTAD-ALI-ASKARI et al, 2016 and OSTAD-ALIASKARI et al, 2017 and SHAYANNEJAD et al, 2015 and ).

The sediment core was calculated from soil mass value divided by water volume for each sample. Then sediment core curve was plotted as a function of time for each irrigation. The mean sediment core at runoff time was calculated from this curve that is area under the net erosion curve divided by runoff time. The total of the net erosion was calculated from multiplication the total volume of runoff by mean sediment core. The total of erosion is total of displaced soil along the furrow that moves to the end.

(RAEISI-VANANI et al, 2015 and SOLTANI-TODESHKI et al, 2015 and ESKANDARI et al, 2017 and RAEISI VANANI et al, 2017)

To study of erosion effect on the furrow shape, cross-section coordinates was measured via profile meter set (Fig6) and maximum depth $\left(Y_{\max }\right)$ was determined before and after irrigation.

( ESLAMIAN et al, 2017 and GODARZI et al, 2016).

\subsection{Statistical Analysis}

The experimental design was randomized complete blocks consisted of four replicated blocks with the three water-quality treatments.

Three furrows (one main furrow and two lateral furrows in order to creation of farm actual conditions (Fig 5)) were applied in each plot. Measurements were done in middle furrow.

In this paper statistical analysis was performed on the mean sediment core, $f_{o}$ and $Y_{\max }$ parameters.

\section{RESULTS AND DISCUSSION}

\subsection{Inflow Water and Wastewater Quality}

The results of the inflow water and wastewater quality are presented in Table 2. According to this table, the biological parameters and TSS of M and W treatments are different with those of F tratment. So TSS of M and W treatments are 5 times of the other treatment. Magnetic field effects on cations, anions, EC, pH, Total-coliform, TSS and COD of wastewater were investigated. It was found that magnetic field effect on cations and anions does not follow any specific trend, but EC increase slightly. Also was found that magnetic field often increases in $\mathrm{pH}$, TSS, COD and total-coliform in the wastewater. 
Wastewater and Magnetized Wastewater Effects on Soil Erosion in Furrow Irrigation

Table 2. Inflow water and wastewater quality in three irrigation events

\begin{tabular}{|c|c|c|c|c|c|c|c|c|}
\hline \multirow{2}{*}{ Parameters } & \multirow{2}{*}{ Unit } & \multirow{2}{*}{ Fresh water } & \multicolumn{3}{|c|}{ Wastewater } & \multicolumn{3}{|c|}{ Magnetized wastewater } \\
\hline & & & Second & Fourth & Fifth & Second & Fourth & Fifth \\
\hline $\mathrm{Na}^{+}$ & $\mathrm{mmol} / \mathrm{l}$ & 5.20 & 9.50 & - & 4.80 & 10.50 & - & 4.80 \\
\hline $\mathrm{K}^{+}$ & $\mathrm{mmol} / \mathrm{l}$ & 0.06 & 0.90 & - & 0.30 & 0.90 & - & 0.30 \\
\hline $\mathrm{Ca}^{2+}$ & $\mathrm{mmol} / \mathrm{l}$ & 2.30 & 2.25 & - & 3.10 & 2.35 & - & 3.20 \\
\hline $\mathrm{Mg}^{2+}$ & $\mathrm{mmol} / \mathrm{l}$ & 0.70 & 0.85 & - & 2.50 & 0.45 & - & 3.10 \\
\hline $\mathrm{HCO}_{3}^{-}$ & $\mathrm{mmol} / \mathrm{l}$ & 7.75 & 4.40 & - & 4.90 & 4.80 & - & 4.80 \\
\hline $\mathrm{CO}_{3}{ }^{2-}$ & $\mathrm{mmol} / \mathrm{l}$ & 0.00 & 0.00 & - & 0.25 & 0.00 & - & 0.30 \\
\hline $\mathrm{SO}_{4}{ }^{2-}$ & $\mathrm{mmol} / \mathrm{l}$ & 0.55 & 0.79 & - & 0.15 & 0.79 & - & 2.10 \\
\hline $\mathrm{Cl}^{-}$ & $\mathrm{mmol} / \mathrm{l}$ & 6.25 & 10.63 & - & 10.60 & 10.63 & - & 8.10 \\
\hline SAR & $(\mathrm{mmol})^{0.5} / 1^{0.5}$ & 4.25 & 7.63 & - & 2.87 & 8.87 & - & 2.70 \\
\hline $\mathrm{pH}$ & - & 7.55 & 8.26 & 7.26 & 8.01 & 8.30 & 7.56 & 7.79 \\
\hline $\mathrm{EC}$ & $\mathrm{dS} / \mathrm{m}$ & 0.656 & 0.990 & 1.095 & 1.099 & 1.002 & 1.108 & 1.100 \\
\hline TSS & $\mathrm{mg} / \mathrm{l}$ & 10 & 60 & 68 & 53 & 61 & 65 & 56 \\
\hline DO & $\mathrm{mg} / \mathrm{l}$ & 6.8 & - & - & - & - & - & - \\
\hline COD & $\mathrm{mg} / \mathrm{l}$ & 0 & 92 & 110 & 84 & 95 & 102 & 93 \\
\hline Total-coliform & MPN/100cc & 0 & $23.3 \times 104$ & $6.9 \times 104$ & $17.6 \times 104$ & $35.6 \times 104$ & $10.5 \times 104$ & $2.0 \times 104$ \\
\hline
\end{tabular}

Note: $S A R=N a /[(C a+M g) / 2]^{0.5} ; M P N:$ Most Probable Number

\subsection{Soil Erosion Analysis}

A sample of inflow and outflow hydrographs and net erosion charts are shown in Fig 7.
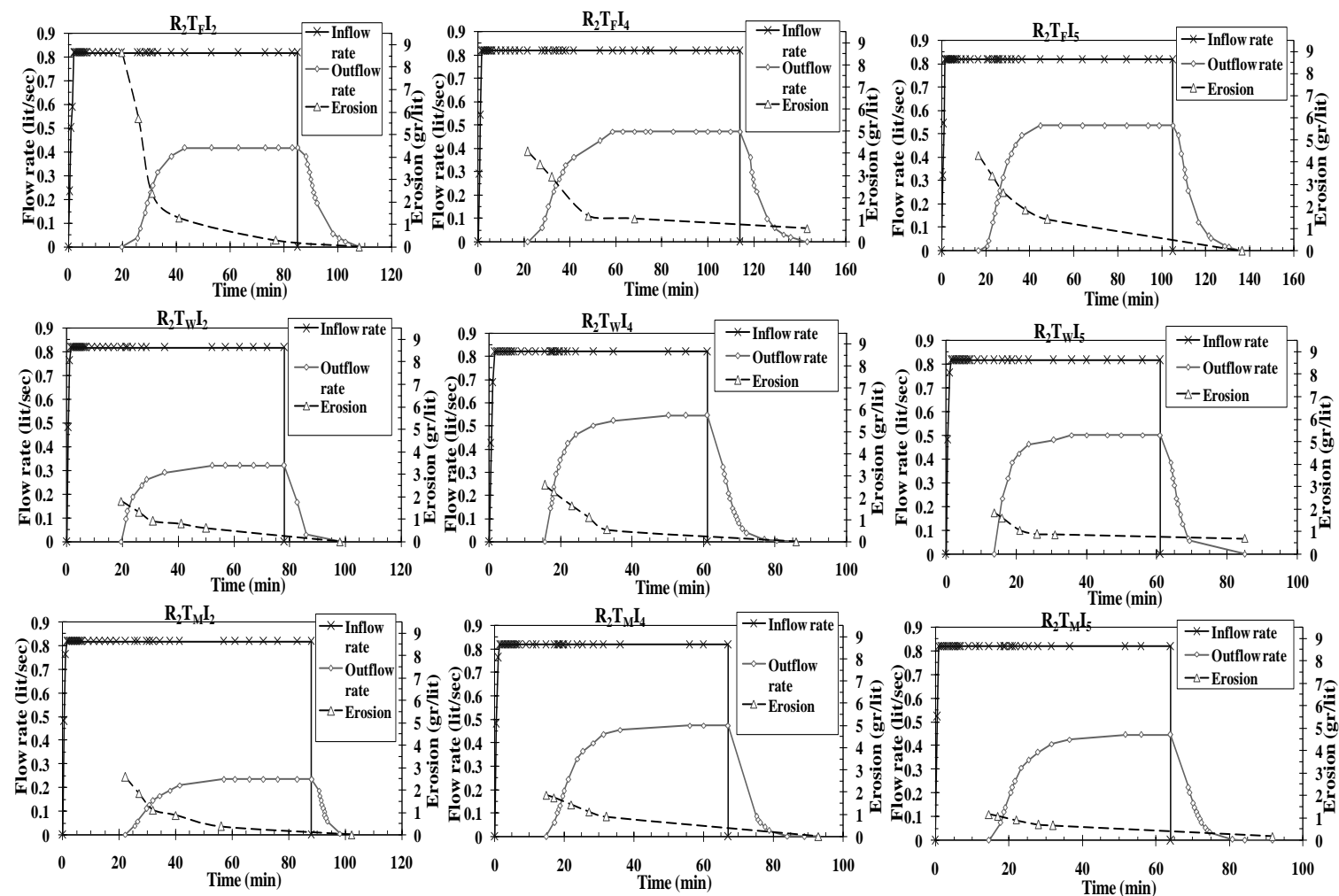

Fig 7. Inlet and outlet hydrographs and net erosion charts for second replication

Note: For example $R_{2} T_{F} I_{2}=$ Riplication 2, fresh water treatment and irrigation event 2;

$R_{2} T_{W} I_{2}=$ Riplication 2, wastewater treatment and irrigation event 2;

$R_{2} T_{M} I_{2}=$ Riplication 2, magnetized wastewater treatment and irrigation event 2.

Results in Fig 7 show that in all of the water treatments net erosion decreases related to time for each irrigation. Mean and total of net erosion were also calculated that are presented in Table 3. 
Table 3. Results of mean and total erosion, basic infiltration rate $\left(f_{o}\right)$ and maximum depth of furrow crosssection in upstream end $\left(Y_{\max }\right)$ and their statistical analysis

\begin{tabular}{|c|c|c|c|c|c|c|c|c|c|c|c|c|c|}
\hline \multirow[b]{2}{*}{ Replication } & \multirow[b]{2}{*}{ Water treatment } & \multicolumn{3}{|c|}{$\begin{array}{l}\text { Mean erosion }(\mathrm{gr} / \mathrm{l}) \\
\text { Irrigation number }\end{array}$} & \multicolumn{3}{|c|}{$\begin{array}{l}\text { Total of erosion (gr) } \\
\text { Irrigation number }\end{array}$} & \multicolumn{3}{|c|}{$\begin{array}{c}f_{0}(\mathrm{~mm} / \mathrm{hr}) \\
\text { Irrigation number }\end{array}$} & \multicolumn{3}{|c|}{$\begin{array}{c}Y_{\max }(\mathrm{cm}) \\
\text { Irrigation number }\end{array}$} \\
\hline & & 2 & 4 & 5 & 2 & 4 & 5 & 2 & 4 & 5 & 2 & 4 & 5 \\
\hline \multirow[t]{3}{*}{$\bar{I}$} & $\mathrm{~F}$ & 0.84 & 1.98 & 1.28 & 718.3 & 770.7 & 626.7 & 85.5 & 68.2 & 68.5 & 17.8 & 19.7 & 20.7 \\
\hline & W & 0.65 & 1.11 & 0.51 & 1046.6 & 1854.5 & 970.3 & 55.1 & 47.2 & 32.1 & 16.2 & 17.1 & 17.6 \\
\hline & M & 0.76 & 0.53 & 0.56 & 1923.7 & 1129.5 & 1328.1 & 32.7 & 25.1 & 21.5 & 17.5 & 18.3 & 18.8 \\
\hline \multirow[t]{3}{*}{ II } & $\mathrm{F}$ & 1.32 & 1.27 & 1.18 & 1117.4 & 1843.2 & 2106.3 & 57.4 & 49.5 & 40.5 & 16.2 & 17.8 & 18.6 \\
\hline & W & 0.57 & 0.59 & 0.88 & 636.8 & 741.6 & 1289.7 & 71.1 & 39.3 & 45.2 & 15.1 & 15.5 & 15.6 \\
\hline & M & 0.55 & 0.65 & 0.53 & 520.2 & 967.8 & 745.2 & 83.6 & 49.2 & 53.4 & 18.9 & 19.0 & 19.0 \\
\hline \multirow[t]{3}{*}{ III } & $\mathrm{F}$ & 0.40 & 0.35 & 0.43 & 959.9 & 724.1 & 935.5 & 65.7 & 50.0 & 47.0 & 17.8 & 19.7 & 20.7 \\
\hline & W & 0.56 & 0.53 & 0.45 & 918.8 & 860.3 & 553.7 & 55.0 & 51.5 & 52.2 & 16.5 & 17.2 & 17.5 \\
\hline & M & 0.85 & 0.48 & 0.37 & 857.7 & 715.0 & 311.9 & 77.5 & 52.5 & 67.3 & 16.2 & 17.2 & 17.7 \\
\hline \multirow[t]{3}{*}{ IV } & $\mathrm{F}$ & 1.04 & 0.73 & 1.31 & 2217.9 & 1684.6 & 3030.8 & 58.0 & 46.3 & 55.1 & 18.8 & 20.8 & 21.8 \\
\hline & W & 0.82 & 0.50 & 0.30 & 1259.3 & 1288.9 & 430.8 & 47.0 & 30.1 & 53.9 & 15.9 & 17.0 & 17.5 \\
\hline & M & 0.42 & 0.51 & 0.31 & 1018.2 & 935.8 & 597.1 & 55.0 & 39.1 & 42.8 & 16.5 & 17.5 & 18.0 \\
\hline \multicolumn{14}{|l|}{ Statistical analysis } \\
\hline & $\mathrm{df}$ & & & & & & & & & & & & \\
\hline Water treatment & 2 & $* *$ & $*$ & $* *$ & - & - & - & NS & NS & NS & NS & NS & NS \\
\hline Replication & 3 & NS & NS & NS & NS & NS & NS & NS & NS & NS & NS & NS & NS \\
\hline Error & 6 & & & & & & & & & & & & \\
\hline Total & 12 & & & & & & & & & & & & \\
\hline Corrected Total & 11 & & & & & & & & & & & & \\
\hline
\end{tabular}

Note: $d f=$ degree of freedom; $N S=$ non significant; $* P<0.05, * * P<0.01$.

Values of basic infiltration rate, maximum depth of furrow cross-section and their statistical analysis are shown in each irrigation event at Table 3 too. Date in Table 3 show that the mean erosion in $\mathrm{W}$ and $\mathrm{M}$ treatments has significantly decreased related to $\mathrm{F}$ treatment. So, there is a significant difference at $1 \%$ level between mean erosion in $\mathrm{W}$ and $\mathrm{F}$ treatments and $\mathrm{M}$ and $\mathrm{F}$ treatments for second and fifth irrigation events and 5\% for fourth irrigation event (due to water quality, EC, SAR,.), but there is no significant difference between $\mathrm{M}$ and $\mathrm{W}$ treatments in all irrigations. The results showed that effect of irrigation events on the mean erosion in all of the treatments was not significant. According to Tables 2 and 3 with increasing amount of suspended and dissolved solids (i. e. capacity reduction of transport soil particles and aggregates) outlet net erosion decreases at the end of the furrows. The results show that increasing in $f_{\mathrm{o}}$ causes decreasing in net erosion, but it had no significant effect on erosion (Table 3). Increasing in $f_{\mathrm{o}}$ can be due to high EC in M treatment that is compliant with OSTER and SCHROER, (1979) report. Magnetizing (according to BOGATIN (1999) results) and high EC are couses of $f_{\mathrm{o}}$ increasing for $\mathrm{M}$ treatment than $\mathrm{W}$ one. Using $\mathrm{M}$ treatment increases soil basic infiltration rate in more cases and this is consistent with founds of BOGATIN (1999). So magnetic field may be cause decrease in net erosion (Table 3) because according to researches of AINA (1993) can be reduced runoff and erosion through improved infiltration capacity.

( OSTAD-ALI-ASKARI et al, 2015 and OSTAD-ALI-ASKARI et al, 2016 and OSTAD-ALIASKARI et al, 2017 and SHOJAEI et al, 2017 and BAHMANPOUR et al, 2017)

Soil erosion decreased during irrigation events in $\mathrm{W}$ and $\mathrm{M}$ treatments (according to Fig 8). We guess that this is due to soil particles stability that can be had a good agreement with results of BISWAS et al (2009). They showed application of effluent increases the soil aggregate stability. Also replacing saline-sodic irrigation water with treated wastewater could have favorable effects on soil structural stability (MANDAL et al, 2008). It is important to note that soil particles stability increases water resistance and consequently decreases soil erosion.

(OSTAD-ALI-ASKARI et al, 2015 and OSTAD-ALI-ASKARI et al, 2016 and OSTAD-ALIASKARI et al, 2017). 


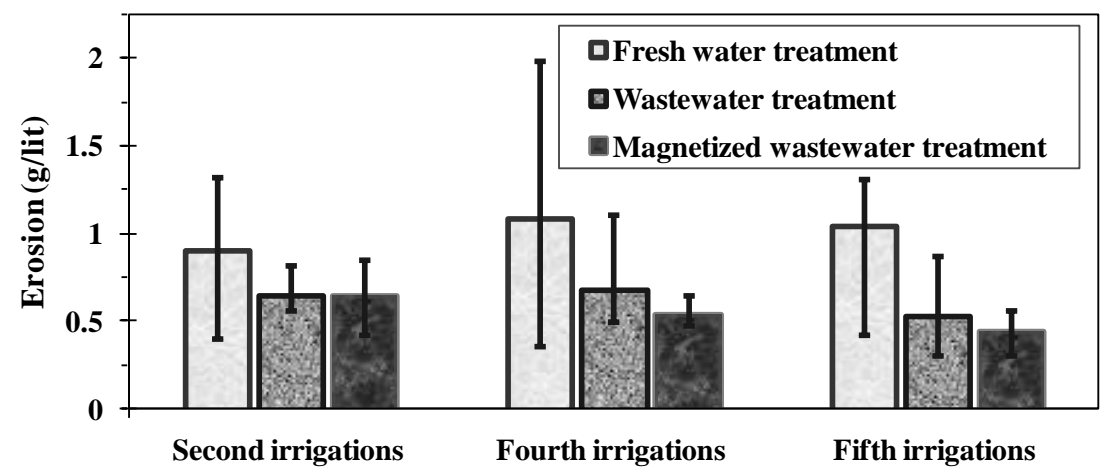

Fig 8. Average erosion in different irrigation events and replications

Note: Error bars show maximum and minimum of the net erosion.

Three water quality treatments caused change in maximum depth $\left(Y_{\max }\right)$ of the furrow cross-section (Fig. 9 and Table 3).

Distance from straight furrow bank (cm)

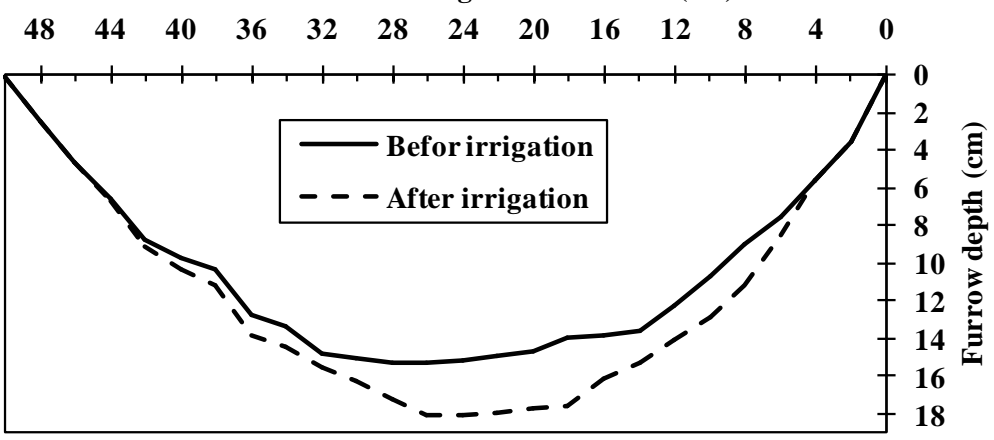

Fig. 9. The sample of furrow cross-section before and after irrigation

Changes of $Y_{\max }$ were also calculated in each treatment related to second irrigation event ( $\left(Y_{\max _{i}}-Y_{\max _{2}}\right) / Y_{\max _{2}}$ that $Y_{\max _{2}}$ is maximum depth in second irrigation event and $i=4$ or 5) (Fig $10)$.
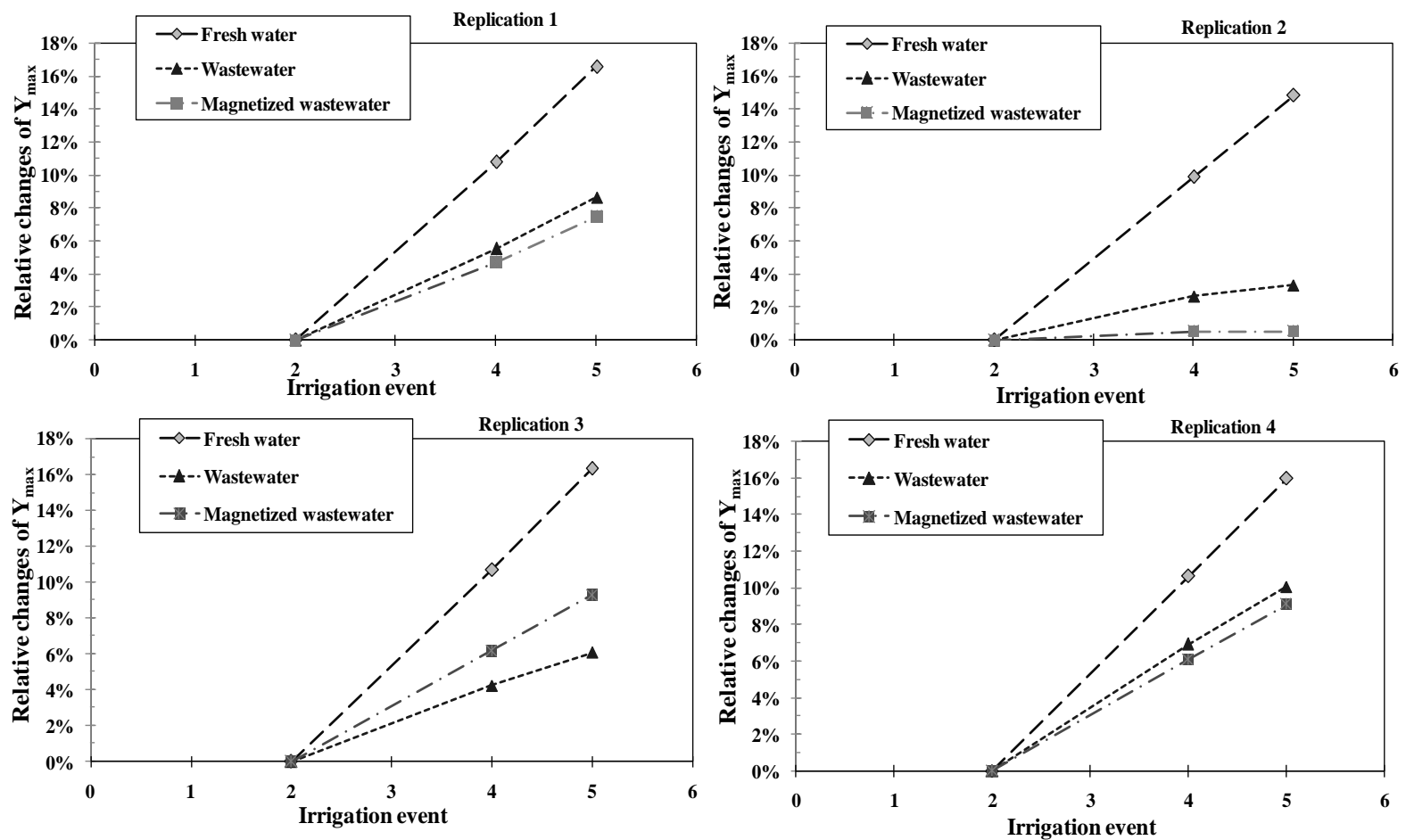

Fig 10. Changes of $Y_{\max }$ in different irrigation events than the second irrigation for treatments

According to Fig 10 changes of $Y_{\max }$ for $\mathrm{F}$ treatment are more than $\mathrm{W}$ and $\mathrm{M}$ treatments in different 
irrigation events that is due to more erosion for $\mathrm{F}$ treatment, but there is no significant difference between treatments.

\section{Conclusion}

1. Magnetic field increased EC and $\mathrm{pH}$ of the wastewater; also it increased TSS, COD and totalcoliform in some cases.

2. In all of the water treatments, net erosion decreases related to time for all of irrigation events.

3. $\mathrm{W}$ and $\mathrm{M}$ treatments decreased mean erosion significantly relative to $\mathrm{F}$ ones. This difference was in the second and forth irrigation events at the $1 \%(\mathrm{p}<0.01)$ and $5 \%(\mathrm{p}<0.05)$ level respectively, but there was no between of $\mathrm{W}$ and $\mathrm{M}$ treatments. These results confirmed this topic that capacity reduction of transport soil particles and aggregates in water treatments decreases soil erosion by these treatments.

4. Magnetizing of wastewater was caused erosion decreasing for $\mathrm{M}$ treatment than $\mathrm{W}$ treatment, because magnetizing caused infiltration increasing so that runoff and thereby soil erosion decreased.

5. Basic infiltration rate of the $\mathrm{M}$ treatment became more than $\mathrm{W}$ and $\mathrm{F}$ ones in more cases that can be caused erosion reduction and this results were also true for $\mathrm{W}$ treatment than $\mathrm{F}$ ones.

6. Changes of maximum depth of furrow cross-section in upstream end for $\mathrm{F}$ treatment were more than $\mathrm{W}$ and $\mathrm{M}$ treatments that shows more erosion for $\mathrm{F}$ treatment.

7. Results of erosion investigation confirmed what is already known that are decreasing of the soil erosion and infiltration increasing for high EC in water treatments.

8. According to this paper results, suggest new research for investigation of different intensity of the magnetic field (created by both of constant magnetic field or electromagnetic field) effects on water and wastewater quality and also on soil erosion.

\section{ACKNOWLEDGEMENT}

The costs of this research were fully provided by the grant of the Isfahan University of Technology, Department of Water Engineering. The writers sincerely appreciate the technical and friendly assistances from Mohammad Arab, Sayyed Adel Sadeghi, Behnaz Khosravi, Hosein Sheybani, Sajjad Rezaee, Amir Hosein Delfruzi, Arabzadegan, Behnaz Harandizade, Paya Tejarat Company and warter engineering, soil science and civil engineering departments, Isfahan University of Technology.

\section{REFERENCES}

[1] AINA P.O. (1993): Soil tillage in Africa: needs and challenges. Food and Agriculture Organization (FAO) Soils bulletin 69.

[2] ANONYMOUS. (1998): Standard methods for the examination of water and wastewater. 20th edition.

[3] ARORA H.S., COLEMAN N.T. (1979): The influence of electrolyte concentration on flocculation of clay suspensions. Soil Science, 127: 134-139.

[4] BEDBABIS S., ROUINA B.B., BOUKHRIS M., FERRARA G. (2014): Effect of irrigation with treated wastewater on soil chemical properties and infiltration rate. Journal of Environmental Management, 133: 45-50.

[5] BISWAS A.K., MOHANTY M., HATI K.M., MISRA A.K. (2009): Distillery effluents effect on soil organic carbon and aggregate stability of a Vertisol in India. Soil and Tillage Research, 104: 241-246.

[6] BJORNEBERG D., SOJKA R., LEYTEM A. (2005): Technologies to minimize water quality impacts of irrigated agriculture. Impacts of Global Climate Change. American Society of Civil Engineers, pp. 1-7.

[7] BOGATIN. J., (1999): Magnetic treatment of irrigation water: experimental results and applications. Environmental Science and Technology. 33: 1280-1285

[8] BOUWER H., IDELOVITCH E. (1987): Quality requirements for irrigation with sewage water. 
Journal of Irrigation and Drainage Engineering. American Society of Civil Engineers, 113 (4): $516-535$.

[9] BROWN L.C., FOSTER G.R., BEASLEY D.B. (1989): Rill. Erosion as affected by incorporated crop residue and seasonal consolidation. Transactions of the American Society of Agricultural Engineers (ASAE), 32: 1967-1978.

[10] CARTER D.L. (1993): Furrow irrigation erosion lowers soil productivity. Journal of Irrigation and Drainage Engineering. American Society of Civil Engineers, 119: 964-974.

[11] CARTER D.L., BROCKWAY C.E., TANJI K.K. (1993): Controlling erosion and sediment loss from furrow- irrigated cropland. Journal of Irrigation and Drainage Engineering. American Society of Civil Engineers, 119 (6): 975-988.

[12] CLEMMENS A.J., BJORNEBERG D.L. (2005): New furrow flume for high sediment loads. Applied Engineering in Agriculture. American Society of Agricultural and Biological Engineers (ASABE), 21: 227-236.

[13] FIRMAN M., BODMAN G.B. (1940): The effect of saline irrigation water upon the permeability and base status of soils. Soil Science Society of America Journal, 4: 71-77.

[14] FORNSTORM K.J., BORRELLI J., LONG J. (1985): Sediment losses from furrow irrigated croplands in Wyoming. Agricultural Engineering Department, University of Wyoming.

[15] FRENKEL H., GOERTZEN J.O., RHOADES J.D. (1978): Effects of clay type and content, exchangeable sodium percentage, and electrolyte concentration on clay dispersion and soil hydraulic conductivity. Soil Science Society of America Journal, 42: 32-39.

[16] GOLDBERG S., GLAUBIG R.A. (1987): Effect of saturating cation, pH, and aluminum and iron oxide on the flocculation of kaolinite and montmorillonite. Clays and Clay Minerals, 35: 220 227.

[17] HAJEK B.F., KARLEN D.L., LOWERY B., POWER J.F., SCHUMACHER T.E., SKIDMORE E.L., SOJKA R.E. (1990): Erosion and soil properties. p. 23-39. In W. E. Larson et al. (ed.) Proc. Soil erosion productiv. Worksh., Bloomington, MN. 13-15 Mar. 1989. University of Minnesota, St. Paul.

[18] HEIDARPOUR M., MOSTAFAZADEH-FARD B., ABEDI KOUPAI J., MALEKIAN R. (2007): The effects of treated wastewater on soil chemical properties using subsurface and surface irrigation methods. Agricultural Water Management, 90: 87-94.

[19] HOZAYN M., ABDEL-MONEM A., QADOS A. (2011): Irrigation with magnetized water: a novel tool for improving crop production in Egypt. World Environmental and Water Resources Congress. American Society of Civil Engineers, pp. 4206-4222.

[20] KAZMAN Z., SHAINBERG I., GAL M. (1983): Effect of low levels of exchangeable Na and applied phosphogypsum on the infiltration rate of various soils. Soil Science, 35: 184-192.

[21] KEMPER W.D., TROUT T.J.,BROWN M.J., ROSENAU R.C. (1985): Furrow erosion and water and soil management. Transactions of the American Society of Agricultural Engineers (ASAE), 28: 1564-1572.

[22] KOLUVEK P.K., KENNETH K.T.,TROUT T.J. (1993): Overview of soil erosion from irrigation. Journal of Irrigation and Drainage Engineering. American Society of Civil Engineers, 119: 929-946.

[23] LENTZ R.D., SOJKA R.E., CARTER D.L. (1996): Furrow irrigation water-quality effects on soil loss and infiltration. Soil Science Society of America Journal, 60 (1): 238-245.

[24] MADISON M., DICKEY J., BURBY B., MILLER T. (2004): Arable lands lost to erosion near Beijing, China: restoration with municipal waste. Critical Transitions in Water and Environmental Resources Management. American Society of Civil Engineers, pp. 1-10.

[25] MALIK M., MUSTAFA M.A., LETEY J. (1992): Effect of mixed Na/Ca solutions on swelling, dispersion and transient water flow in unsaturated montmorillonitic soils. Geoderma, 52:17-28.

[26] MAMEDOV A.I., SHAINDERG I., LEVY G.J. (2000): Irrigation with effluent water: effects of rainfall energy on soil infiltration. Soil Science Society of America Journal, 64: 732-737.

[27] MANDAL U.K., BHARDWAJ A.K., WARRINGTON D.N., GOLDSTEIN D., TAL A.B., 
LEVY G.J. (2008): Changes in soil hydraulic conductivity, runoff, and soil loss due to irrigation with different types of saline-sodic water. Geoderma, 144: 509-516.

[28] MOSTAFAZADEH-FARD B., KHOSHRAVESH M., MOUSAVI S., KIANI A. (2011): Effects of magnetized water and irrigation water salinity on soil moisture distribution in trickle irrigation. Journal of Irrigation and Drainage Engineering. American Society of Civil Engineers, 137 (6): 398-402.

[29] MOSTAFAZADEH-FARD B., KHOSHRAVESH M., MOUSAVI S., KIANI A. (2012): Effects of magnetized water on soil chemical components underneath trickle irrigation. Journal of Irrigation and Drainage Engineering. American Society of Civil Engineers, 138 (12): 1075-1081.

[30] OSTER J.D., SCHROER F.W. (1979): Infiltration as influenced by irrigation water quality. Soil Science Society of America Journal, 43: 444-447.

[31] QUIRK J.P., SCHOFIELD R.K. (1955): The effect of electrolyte concentration on soil permeability. Journal of Soil Science, 6: 163-178.

[32] ROBBINS C.W., BROCKWAY C.E. (1978): Irrigation water salt concentration influences on sediment removal by ponds. Soil Science Society of America Journal, 42: 478-481.

[33] SEPASKHAH A.R., SHAHABIZAD V. (2010): Effects of water quality and PAM application rate on the control of soil erosion, water infiltration and runoff for different soil textures measured in a rainfall simulator. Biosystems Engineering, 106: 513-520.

[34] SHAINBERG I., WARRINGTON D., LAFLEN J.M. (1992): Soil dispersibility, rain properties, and slope interaction in rill formation and erosion. Soil Science Society of America Journal, 56: 278-283.

[35] SIEGRIST R., BOYLE W. (1987): Wastewater-induced soil clogging development. Journal of Environmental Engineering. American Scosiety of Civil Engineering, 113 (3): 550-566.

[36] SMITH G.G., FOLEY J.L., LOCH R.J. (1992): Effects of electrical conductivity of water used in wetting and in wet sieving on measured aggregate water stability. Soil Technology, 5: 177-184.

[37] STHIANNOPKAO S., TAKIZAWA S., HOMEWONG J., WIROJANAGUD W. (2007): Soil erosion and its impacts on water treatment in the northeastern provinces of Thailand. Environment International, 33: 706-711.

[38] TROUT T.J., NEIBLING W.H. (1993): Erosion and sedimentation processes on irrigated fields. Journal of Irrigation and Drainage Engineering. American Society of Civil Engineers, 119: 947963.

[39] VELASCO-MOLINA H.A., SWOBODA A.R., GODFREY C.L. (1971): Dispersion of soils of different mineralogy in relation to sodium adsorption ratio and electrolytic concentration. Soil Science, 111: 282-287.

[40] WISCHMEIER W.H., MANNERING J.V. (1969): Relation of soil properties to its erodibility. Soil Science Society of America Journal, 33: 131-130.

[41] WALLACE A., TERRY R.E. (1998): Soil conditioners, soil quality and soil sustainability. Marcel Dekker, New York, NY, pp. 1-41.

[42] Ostad-Ali-Askari, K., Shayannejad, M. 2015, Study of sensitivity of Autumnal wheat to under irrigation in Shahrekord, Shahrekord City, Iran. International Journal of Agriculture and Crop Sciences, 8 (4), 602-605.

[43] Shayannejad, M., Akbari, N., Ostad-Ali-Askari, K. 2015, Study of modifications of the river physical specifications on muskingum coefficients, through employment of genetic algorithm. International Journal of Development Research, 5(3), 3782-3785.

[44] Ostad-Ali-Askari, K., Shayannejad, M. 2015, The Reviews of Einstein's Equation of Logarithmic Distribution Platform and the Process of Changes in the Speed Range of the Karkheh River, Khuzestan province, Iran. International Journal of Development Research, 5(3), 3786-3790.

[45] Ostad-Ali-Askari, K., Shayannejad, M., Ghorbanizadee-Kharazi, H. 2015, Assessment of artificial neural network performance and exponential regression in prediction of effective rainfall, International Journal of Development Research, 5(3), 3791-3794.

[46] Shayannejad, M. Akbari, N. and Ostad-Ali-Askari, K. 2015, Determination of the nonlinear 
Muskingum model coefficients using genetic algorithm and numerical solution of the continuity. Int. J. of Science: Basic and Applied Research, 21(1),1-14.

[47] Ostad-Ali-Askari, K., Shayannejad, M. 2015, The Study of Mixture Design for Foam Bitumen and the Polymeric and Oil Materials Function in Loose Soils Consolidation. Journal of Civil Engineering Research, 5(2), 39-44. DOI: 10.5923/j.jce.20150502.04

[48] Sayedipour, M., Ostad-Ali-Askari, K., Shayannejad, M. 2015, Recovery of Run off of the Sewage Refinery, a Factor for Balancing the Isfahan-Borkhar Plain Water Table in Drought Crisis Situation in Isfahan Province-Iran. American Journal of Environmental Engineering, 5(2): 43-46. DOI: 10.5923/j.ajee.20150502.02

[49] Ostad-Ali-Askari, K., Shayannejad, M. 2015, Developing an Optimal Design Model of Furrow Irrigation Based on the Minimum Cost and Maximum Irrigation Efficiency. International Bulletin of Water Resources \& Development, 3(2), 18-23.

[50] Ostad-Ali-Askari, K., Shayannejad, M. 2015, Presenting a Mathematical Model for Estimating the Deep Percolation Due to Irrigation. International Journal of Hydraulic Engineering, 4(1), 17 21. DOI: $10.5923 /$ j.ijhe.20150401.03.

[51] Ostad-Ali-Askari, K., Shayannejad, M. 2015, Usage of rockfill dams in the HEC-RAS software for the purpose of controlling floods. American Journal of Fluid Dynamics, 5(1), 23-29. DOI: 10.5923/j.ajfd.20150501.03.

[52] Raeisi-Vanani, H., Soltani Todeshki, A. R., Ostad-Ali- Askari, K., Shayannejad, M. 2015, The effect of heterogeneity due to inappropriate tillage on water advance and recession in furrow irrigation. Journal of Agricultural Science, 7(6), 127-136.

[53] Soltani-Todeshki, A. R., Raeisi-Vanani, H., Shayannejad, M., Ostad-Ali-Askari, K. 2015, Effects of magnetized municipal effluent on some chemical properties of soil in furrow irrigation. International Journal of Agriculture and Crop Sciences, 8(3), 482-489.

[54] Ostad-Ali-Askari, K., Shayannejad, M. 2015, Optimal design of pressurized irrigation laterals installed on sloping land. International Journal of Agriculture and Crop Sciences, ISSN 2227670X. 8(5), 792-797.

[55] Ostad-Ali-Askari K, Shayannejad M, Eslamian S, Navab-Pour B. 2016, Comparison of solution of Saint-Venant equations by characteristics and finite difference methods for unsteady flow analysing in open channel. International Journal of Hydrology Science and Technology, 6(3), 918.

[56] Ostad-Ali-Askari K, Shayannejad M, Eslamian S, et al. 2017, Deficit Irrigation: Optimization Models. Management of Drought and Water Scarcity. Handbook of Drought and Water Scarcity, Taylor \& Francis Publisher, USA. Vol.3. 1th Edition, pp: 373-389.

[57] Eskandari S, Hoodaji M, Tahmourespour A, Abdollahi A, Mohammadian-Baghi T, Eslamian S, Ostad-Ali-Askari K. 2017, Bioremediation of Polycyclic Aromatic Hydrocarbons by Bacillus Licheniformis ATHE9 and Bacillus Mojavensis ATHE13 as Newly Strains Isolated from OilContaminated Soil. Journal of Geography, Environment and Earth Science International, 11(2): $1-11$.

[58] Raeisi Vanani H, Shayannejad M, Soltani Tudeshki A.R, Ostad-Ali-Askari K, Eslamian S, et al. 2017, Development of a new method for determination of infiltration coefficients in furrow irrigation with natural non-uniformity of slope. Sustain. Water Resour. Manag., 3(2): 163-169.

[59] Shojaei N, Shafaei-Bejestan M, Eslamian S, Marani-Barzani M, P. Singh V, Kazemi M, OstadAli-Askari K. 2017, Assessment of Drainage Slope on the Manning Coarseness Coefficient in Mountain Area. International Journal of Constructive Research in Civil Engineering (IJCRCE), 3(1): 33-40.

[60] Bahmanpour H, Awhadi S, Enjili J, Hosseini S.M, Raeisi Vanani H, Eslamian S, Ostad-AliAskari K. 2017, Optimizing Absorbent Bentonite and Evaluation of Contaminants Removal from Petrochemical Industries Wastewater. International Journal of Constructive Research in Civil Engineering (IJCRCE), 3(2): 34-42.

[61] Shayannejad M, Eslamian S, Gandomkar A, Marani-Barzani M, Amoushahi-Khouzani M, Majidifar Z, Rajaei-Rizi F, Kazemi M, P. Singh V, Dehghan SH, Shirvani-Dastgerdi H.R, 
Norouzi H, Malekian A, Ostad-Ali-Askari K. 2017, A Proper Way to Install Trapezoidal Flumes for Measurements in Furrow Irrigation Systems. International Journal of Research Studies in Agricultural Sciences (IJRSAS), 3(7): 1-5.

[62] Dehghan Sh, Kamaneh S.A.A., Eslamian S, Gandomkar A, Marani-Barzani M, AmoushahiKhouzani M, Singh V.P., Ostad-Ali-Askari K. 2017, Changes in Temperature and Precipitation with the Analysis of Geomorphic Basin Chaos in Shiraz, Iran.International Journal of Constructive Research in Civil Engineering (IJCRCE), 3(2):1-8.

[63] Eslamian S, Mirabbasi-Najafabadi R, Ostad-Ali-Askari K. Advance Engineering Statistics (Simulation and Modeling of Uncertainty and Sensitivity Analysis). Kankash Publisher. First Edition, 2017. ISBN: 978-600-136-359-7. Isfahan, Iran.

[64] Ostad-Ali-Askari K, Shayannejad M. 2016, FLOOD ROUTING IN RIVERS BY MUSKINGUM'S METHOD WITH NEW ADJUSTED COEFFICIENTS. International Water Technology Journal, IWTJ, 6(3):189-194.

[65] Godarzi A, Eslamian S, Ostad-Ali-Askari K. Water in Literature Aspects (Social and Cultural Aspects). Publication of Tehran Municipality. First Edition, 2016. ISBN: 978-600-439-096-5. Tehran, Iran.

[66] Ostad-Ali-Askari K, Eslamian S, Shayannejad M, et al. Groundwater Hydrodynamic. Horoufchin Publisher. First Edition, 2016. ISBN: 978-600-7419-53-3. Isfahan, Iran.

[67] Ostad-Ali-Askari K, Shayannejad M, Ghorbanizadeh-Kharazi H. 2017, Artificial Neural Network for Modeling Nitrate Pollution of Groundwater in Marginal Area of Zayandeh-rood River, Isfahan, Iran. KSCE Journal of Civil Engineering, 21(1):134-140. Korean Society of Civil Engineers. DOI 10.1007/s12205-016-0572-8.

Citation: H. Raeisi Vanani, et al." Wastewater and Magnetized Wastewater Effects on Soil Erosion in Furrow Irrigation", International Journal of Research Studies in Agricultural Sciences (IJRSAS), vol. 3, no. 8, p. 14, 2017, http://dx.doi.org /10.20431/2454-6224.0308001.

Copyright: () 2017 Authors. This is an open-access article distributed under the terms of the Creative Commons Attribution License, which permits unrestricted use, distribution, and reproduction in any medium, provided the original author and source are credited. 